\title{
Wacana“Ajeg Bali” Pada Seni Kerajinan Sarana Upacara Di Gianyar Bali
}

\author{
NI KADEK KARUNI ${ }^{1}$, I WAYAN SUARDANA ${ }^{2}$ \\ 1.2. Program Studi Kriya Seni, Fakultas Seni Rupa dan Desain, Institut Seni Indonesia Denpasar, Indonesia \\ E-mail : kadekkaruni@ymail.com
}

Dalam usaha mengantisipasi tergerusnya seni budaya Bali yang adiluhung, Bali post dan Bali TV meluncurkan wacana "Ajeg Bali" yang artinya menjaga dan melestarikan identitas budaya Bali agar tidak jatuh di bawah hegemoni budaya global. Penelitian ini ingin mengungkap peranan wacana Ajeg Bali dalam meningkatkan seni kerajinan sarana upacara, dan perubahan sikap hidup masyarakat dalam melakukan upacara adat dan agama. Hal ini perlu diketahui agar konsep Ajeg Bali sesuai dengan tujuan dan sasaran yang dikehendaki. Oleh karena itu, diperlukan pendekatan estetika dan sosiologi, yang dipergunakan untuk menganalisis karya seni dan perubahan sosial kehidupan masyarakat dengan adanya wacana Ajeg Bali. Metode penelitian yang digunakan adalah metode kualitatif dengan analisis deskriptif analitik. Hasil penelitian menunjukkan, bahwa Wacana Ajeg Bali berperan sangat besar dalam pengembangan seni kerajinan sarana upacara yang ada di Gianyar Bali. Wacana ajeg Bali ini diaktualisasikan dengan meningkatkan berbagai aktivitas upacara adat dan agama serta aktif melakukan persembahyangan ke berbagai Pura yang tersebar luas di seluruh Pulau Bali, yang disebut dengan "Rekreasi Religius" Meningkatnya aktivitas upacara dan rekreasi religius, memerlukan berbagai sarana upacara dengan tampilan yang indah dan menarik. Para perajin melihat peluang ini sangat pontensial dan mulai mengembangkan kreativitasnya untuk menciptakan sarana upacara yang baru dengan tetap memiliki identitas Bali. Di berbagai wilayah Kabupaten Gianyar mulai banyak tersebar seni kerajinan sarana upacara seperti di kecamatan Tegallalang, Payangan, Sukawati, dan Tampaksiring. Banyaknya aktivitas upacara adat dan agama, dan tingginya keinginan masyarakat untuk memiliki sarana upacara dengan berbagai bentuk dan jenis, memberi motivasi yang tinggi pada perajin untuk menciptakan sarana upacara yang lebih unik dan menarik.

Kata kunci : Ajeg Bali, rekreasi religius, dan sarana upacara

\section{The Discourse Of "Ajeg Bali" In The Art Crafts For Ceremonial Facilities In Gianyar Bali}

In an effort to anticipate the decrease of Balinese art culture, adiluhung, Bali Post and Bali TV have published a discourse of "Ajeg Bali" which means to protect and to preserve Balinese culture from falling victim to global hegemony. This research has been conducted as a means of knowing the influence discourse of "Ajeg Bali" has in increasing the art crafts of ceremonial facilities, and the changes in society's attitude in performing tradition and religious ceremony as well. These are paramount to knowing whether the concept of "Ajeg Bali" is appropriate to the goal and target stated. That is why, an aesthetic and sociological approach is required to analyze the art works and social life changes of the society by means of discourse in "Ajeg Bali". The research method used in this study was qualitative method by analytic description. The result of this study shows that the discourse of "Ajeg Bali" plays an important role in developing the art crafts of ceremonial facilities in Gianyar Bali. It is promoted through intensifying of various events such as traditional and religious ceremonies as well as ritual of prayers held in temples spread out over Bali known as "Religious Recreation". This increase in activities of ceremony and religious recreation has led to an increasing demand for artistic and attractive facilities for various ceremonies. Craftsmen see this as a promising opportunity and begin to improve their creative process in producing new ceremonial facilities that retain Balinese identity. In Gianyar Regency, there are many craft centers producing ceremonial facilities that have begun to grow, such as those in subdistricts of Tegallallang, Sukawati, Tampaksiring, and Blahbatuh. The rise of activities of tradition and religious ceremony and the high of society willing to have ceremony facilities with various shape and type, has given high motivation to craftsmen to produce more unique and interesting ceremonial facilities.

Keywords: Ajeg Bali, religious recreation, ceremonial facility 


\section{PENDAHULUAN}

Terkenalnya Bali sebagai tujuan wisata internasional karena di samping keindahan alam yang eksotik, juga didukung oleh aktivitas seni budaya Bali yang sangat unik dan menarik. Berbagai aktivitas upacara agama dan adat dapat disaksikan di Bali yang selalu dibarengi dengan berbagai tampilan kesenian baik seni rupa maupun seni pertunjukan yang disajikan oleh masyarakat dengan konsep ngayah (pengabdian).

Masyarakat Bali adalah masyarakat yang terbuka dan selektif yaitu membuka diri datangnya budaya luar dan selektif untuk memilah-milah yang baik diterima dan yang kurang cocok dibuang. Tidak jarang budaya luar beralkulturasi dengan budaya Bali, sehingga lahirlah budaya baru yang berlandaskan budaya lokal yang sangat kental yang kemudian membentuk globalisasi yang dapat memperkaya dan memperkuat budaya Bali. Hal ini terjadi karena budaya Bali memiliki sifat yang elastis dan adaptif (Ardana, 2007: 7).

Walaupun masyarakat Bali sangat fleksibel dan selektif dalam menerima pengaruh budaya luar, para cendikiawan dan pemegang kebijakan Bali sangat khawatir dengan derasnya pengaruh luar yang mempengaruhi budaya tradisi Bali yang sangat adiluhung. Berbagai usaha dan tindakan yang dilakukan pemerintah Bali untuk mengantisipasi hal tersebut agar tradisi budaya Bali tidak terkubur di negerinya sendiri. Gubernur Bali Ida Bagus Mantra membangun Taman Budaya Werdhi Budaya sebagai pusat perhelatan seni, baik seni rupa maupun seni pertunjukan. Untuk memproduktifkan Taman Budaya, Gubernur Ida Bagus Mantra mencetuskan Pesta Kesenian Bali (PKB) yang dilaksanakan setiap tahun sekali selama sebulan penuh. Tujuan PKB di samping untuk merevitalisasi seni Bali yang hampir punah, juga sebagai ajang publikasi berbagai seni budaya Bali yang tersebar luas di seluruh daerah di Bali. Berbagai seni budaya Bali ditampilkan dalam PKB dari yang klasik, tradisi, modern, post modern, dan kolaborasi.

Apabila dicermati secara mendalam, tanpa disadari bahwa PKB merupakan ajang antisipasi menjaga tradisi budaya Bali oleh budaya luar yang maha dahsyat. PKB merupakan ajang melestarikan tradisi budaya Bali agar tidak hilang begitu saja tertelan jaman. Konsep "Ajeg Bali" telah tertuang dalam agenda tahunan ini, tetapi lebih berorientasi pada tindakan dan belum didukung dengan wacana yang gencar.

Wacana Ajeg Bali mulai dirumuskan ketika Bali mengalami musibah besar yaitu adanya Bom Bali I pada tanggal 12 Oktober 2002. Masyarakat Bali ter- lena dengan hingar-bingar pariwisata yang gemerlap dan keyakinan Bali sebagai daerah yang paling aman dan nyaman.

Musibah dahsyat membuka mata dan telinga tokoh-tokoh masyarakat Bali untuk melihat kembali keterbukaan Bali di samping untuk wisatawan, tetapi juga penduduk pendatang yang mau mengadu nasib di Bali. Mereka menyadari bahwa predikat Bali yang aman dan nyaman sudah hilang yang berdampak pada kurangnya minat wisatawan untuk berlibur ke Bali. Bom Bali merupakan suatu isyarat, suatu tanda peringatan, agar masyarakat Bali selalu waspada menjaga keharmonisan Bali, identitas Bali agar "Ajeg" tidak sirna ditelan perubahan. Dari sinilah mulai muncul wacana untuk meng-Ajeg-kan Bali. "Ngiring sarengsareng ngerajegan jagat Baline (mari bersama-sama menjaga jati diri Bali) (Agung, 2005: xii).

Wacana Ajeg Bali bergelora di seluruh seantero masyarakat Bali dari pelosok pegunungan, desa-desa, perkotaan, dan kota besar. Wacana Ajeg Bali memperoleh sambutan luar biasa dari masyarakat Bali. Hal ini tidak bisa dilepaskan dari modernisasi dan Globalisasi yang mengakibatkan masyarakat Bali mengalami perubahan sosial budaya yang hebat dan kompleks dan mengancam identitas masyarakat Bali (Atmadja, 2010: 3). Masyarakat mulai disadarkan untuk menjaga Bali dalam setiap lini kehidupannya, dari sikap hidup, berkomunikasi yang baik, cara berpakaian Bali yang benar, tata pergaulan yang santun, serta dalam melakukan segala aktivitas adat dan agama yang tetap berlandaskan pada jadi diri Bali yang bertaksu yaitu memiliki energi yang kuat dan suci. Dalam usaha untuk mencapai keseimbangan dan keharmonisan antara jasmani dan rohani, masyarakat Bali mulai meningkatkan nilai spiritualitasnya, selain melakukan berbagai upacara, juga banyak melakukan persembahyangan ke berbagai Pura yang ada di seluruh daerah di Bali. Aktivitas ini sering disebut dengan "Rekreasi Religius" yaitu berbhakti sambil berwisata.

Meningkatnya aktivitas upacara agama dan adat serta rekreasi religius masyarakat Bali, memerlukan berbagai bentuk dan jenis sarana upacara yang unik dan artistik. Masyarakat akan selalu memanfaatkan sarana upacara yang indah untuk tempat sesajen yang dihaturkan di Pura maupun tempat lainya. Masyarakat akan selalu ingin mendapatkan sarana upacara yang terbaru dan memiliki identitas Bali yang kental.Masyarakat Bali memiliki jiwa gengsi yang tinggi, terutama berkaitan dengan penampilan sarana persembahan. Jiwa dan sifat masyarakat ini pada akhirnya akan melahirkan karya seni yang semakin bervariatif karena tuntutan keindahan menjadi sangat penting dalam sebuah persembahan. Hal ini juga didasari bahwa apa 
yang masyarakat lakukan merupakan rasa tanggung jawab sebagai orang Bali dalam ikut mendukung wacana Ajeg Bali.

Suatu hal yang sangat membanggakan adalah untuk mendukung wacana Ajeg Bali, masyarakat Bali sangat antusias untuk memiliki berbagai bentuk dan jenis sarana upacara, tidak saja akan digunakan dalam menghaturkan persembahan, tetapi sebagai barang koleksi dan hiasan dalah rumahnya. Masyarakat akan merasa bangga apabila memiliki koleksi sarana upacara dengan berbagai bentuk yang bervariasi dengan material dan teknik yang berbeda. Masyarakat tidak mau ketinggalan dengan produk sarana upacara yang sedang trendi pada waktu tertentu dan akan berusaha untuk mendapatkan sebagai barang koleksinya. Trendi suatu produk sarana upacara yang baru adalah ketika dilangsungkannya Pesta Kesenian Bali (PKB) di Taman Budaya, karena produk baru akan selalu dipamerkan di tempat ini. Oleh sebab itu PKB selalu menjadi barometer perkembangan sebuah produk baru terutama yang berkaitan dengan sarana upacara yang sebagian besar konsumennya penduduk lokal.Kondisi ini menjadi peluang yang sangat terbuka bagi para perajin sarana upacara untuk menciptakan karya-karya baru yang memiliki nilai artistik yang tinggi di samping nilai fungsionalnya. Bentuk dan jenis sarana upacara bermunculan, baik dalam bentuk ukiran kayu, anyaman, cetakan, maupun rakitan. Hal yang sangat menarik adalah pemanfaatan ornamen menjadi suatu yang sangat dominan sebagai penambah artistik yang diterapkan baik dalam bentuk ukiran langsung, cetakan, batik, maupun sunggingan. Kreativitas dan inovasi perajin yang tinggi dalam melahirkan karya yang sangat bervariatif menyebabkan dinamika seni kerajinan sarana upacara berkembang sangat pesat.

Gianyar merupakan salah satu tempat kelahiran seni kerajinan sarana upacara yang tersebar di beberapa kecamatan yaitu Tegallalang, Payangan Sukawati,dan Tampaksiring. Berbagai bentuk dan jenis kerajinan sarana upacara tercipta di tempat ini seperti wanci, tokasi, pemuspan, dan bokoran, dengan menggunakan bahan kayu, rotan, daun lontar, dengan teknik ukir kayu, anyaman, cetakan, dan sungging. Fenomena ini sangat menarik untuk diteliti dan lebih mendalami tentang Bagaimana peranan wacana Ajeg Bali dalam meningkatkan dinamika seni kerajinan sarana upacara di Gianyar Bali terkait dengan berbagai Bentuk, teknik, dan jenis, sarana upacara apa saja yang diproduksi oleh perajin dan diminati oleh masyarakat.

\section{METODE PENELITIAN}

Penelitian ini menggunakan metode kualitatif yaitu pengamatan, wawancara, dan penelaahan dokumen. Metode ini digunakan karena lebih mudah berhadapan dengan kenyataan, menyajikan secara langsung hubungan antara peneliti dan responden, lebih peka dan lebih dapat menyesuaikan diri pola-pola nilai yang dihadapi (Moleong, 2013: 10). Lokasi penelitian ini adalah wilayah Kabupaten Gianyar, karena seni kerajinan sarana upacara banyak tersebar luas di beberapa kecamatan yaitu Tegallalang, Sukawati, Payangan, dan Tampaksiring. Berbagai macam dan jenis seni kerajinan sarana upacara tercipta di tempat ini dengan bahan, teknik, dan tampilan yang berbeda.Populasi dalam penelitiam ini adalah semua jenis kerajinan sarana upacara yang ada di Kabupaten Gianyar. Sedangkan sampelnya adalah masing-masing kecamatan diambil 3 sentra kerajinan dan 3 pedagang kerajinan yang dianggap dapat mewakili wilayah tersebut. Pengambilan sampel bukan melalui jumlah atau sampel acak, melainkan digunakan teknik porposive sampling (sampel bertujuan), dengan alasan bahwa tiap wilayah memiliki identitas karya seni kerajinan yang berbeda.Teknik Pengumpulan Data penelitian secara maksimal ditempuh melalui studi pustaka, observasi, wawancara, dan dokumentasi.

Analisis data meliputi berbagai tahapan: Pertama identifikasi data, mengumpulkan data verbal dan data visual, baik yang diperoleh melalui studi pustaka, observasi, maupun wawancara. Kedua klasifikasi data yaitu memilih atau mengelompokkan data yang telah teridentifikasi sesuai dengan jenis dan sifat data. Ketiga seleksi data yaitu menyisihkan data-data yang tidak relevan dan kurang berkontribusi terhadap kebutuhan dalam pembahasan pokok. Tahap keempat melakukan analisis sesuai dengan teori yang telah ditetapkan, dengan menggunakan analisis kualitatif analitik.

\section{PEMBAHASAN}

\section{Bentuk Dan Jenis Seni Kerajinan Sarana Upaca- ra}

Dalam mencermati bentuk produk seni, Feldman menyatakan bahwa bentuk merupakan manifestasi fisik dari suatu objek yang bisa diamati, memiliki makna, dan berfungsi secara struktural pada objek seni (Feldman, 1967: 30). Teori ini bila disandingkan dengan teori Clive Bell akan mendapatkan pola yang tidak jauh berbeda, bahwa seni itu merupakan perbuatan menampilkan bentuk yang bermakna (significant form). Bentuk seperti ini adalah yang perlu ditampung oleh perasaan estetik, karena itu tak akan terlalu salah kiranya kalau dikatakan bahwa bentuk yang dimaksud adalah yang estetik sifatnya (Clive Bell dalam Sahman, 1993: 15). 

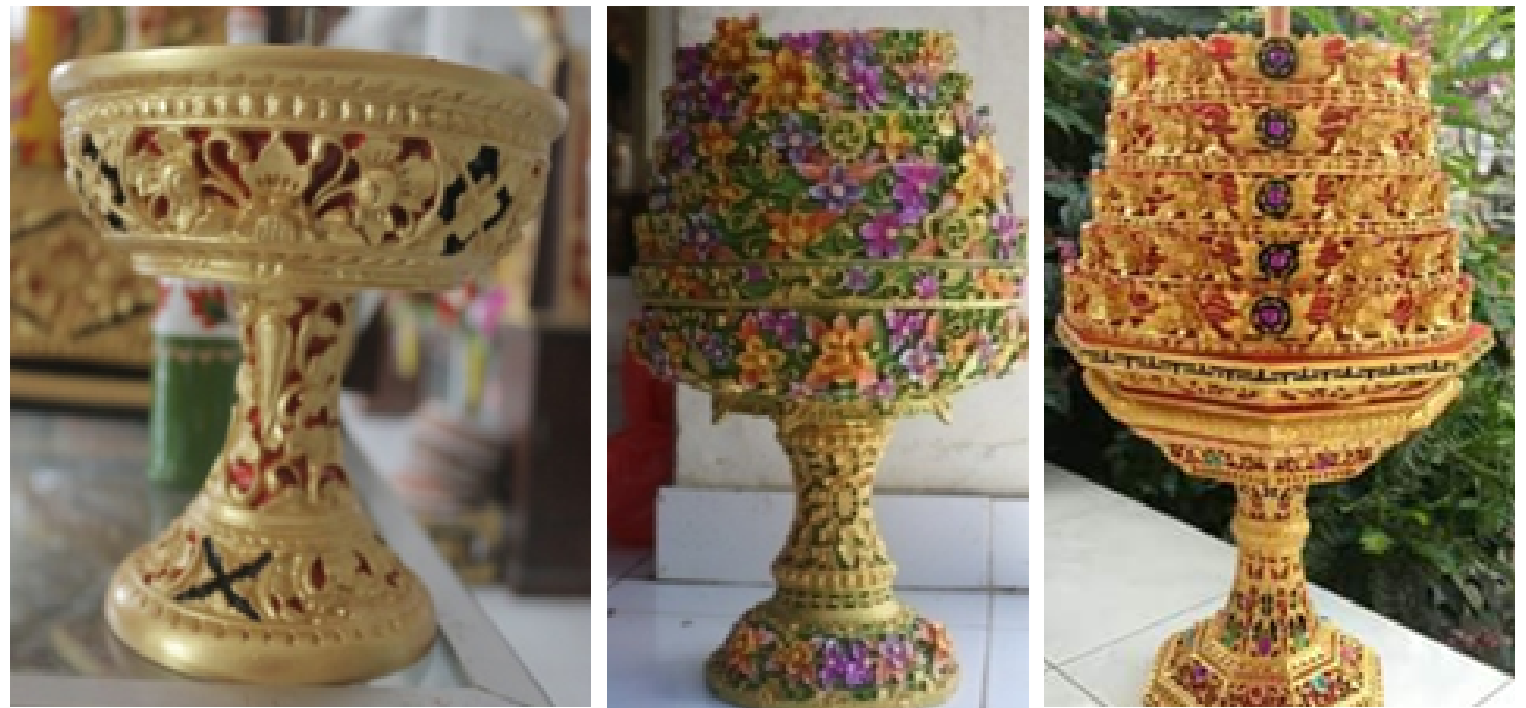

Gambar 1. Bentuk Dulang sederhana dengan kombinasi motif tradisional Bali kemudian dikembangkan Dulang atau wanci berbentuk segi delapan dengan warna yang bervariatif.

Sumber: Perajin dulang di Desa Bresela Payangan.

Sementara Soedarso menjelaskan seni yang tinggi adalah seni yang mengekspresikan ide atau isi yang hebat dengan visualisasi yang tepat dan jelas. Seni selalu terdiri dari bentuk dan isi. Dalam "isi" seorang seniman menunjukkan daerah perhatian atau minatnya, sedangkan pada "bentuk" ia menunjukkan kreativitas dan kecerdasannya dalam memvisualisasikan isi hatinya (Soedarso Sp, 2006: 129). Di samping bentuk dan isi perlu juga dikenali tiga hal utama dalam dimensi fisik karya seni, yakni subject matter, medium dan form (Marianto, 2002: 3). Materi subjek (subject matter) dalam karya seni adalah figur figur, objek-objek, tempat-tempat dan peristiwa-peristiwa yang dilukiskan suatu karya seni. Dalam hal ini objek dimaksud adalah berbagai macam bentuk produk seni kerajinan sarana upacara, sedangkan medium adalah istilah yang dipakai dalam mengkategorikan fisik karya seni secara umum. Dalam penelitian ini medium adalah materi fisik berupa produk karya seni kerajinan berasal dari bahan baku kayu, feber, bambu yang dipergunakan untuk membuat berbagai macam bentuk produk seni kerajinan sarana upacara.

Terkait dengan bentuk produk seni kerajinan sarana upacara, merupakan produk budaya bangsa yang memiliki nilai seni dan ekonomi. Amatan terhadap produk seni kerajinan sarana upacara menunjukkan bahwa keragaman bentuk produk yang muncul di samping mengindikasikan adanya proses keberlangsungan aktivitas yang diwariskan dari tradisi sebelumnya, juga menandakan adanya perubahan. Perubahan sosial budaya masyarakat Bali khususnya masyarakat Hindu juga sangat mempengaruhi bentuk, teknik, motif dan fungsi produk yang dihasilkan. Perubahan dan perkembangan itu sangat wajar da- lam rangka menyesuaikan dengan situasi dan kondisi yang senantiasa selalu berubah sesuai dengan tuntutan zaman.

Segala macam bentuk dan jenis seni kerajinan sarana upacara yang tumbuh dan berkembang di Gianyar, masing-masing wilayah memiliki identitasnya sendiri walaupun materialnya sama. Bila diamati dengan cermat, karya seni tiap-tiap daerah memiliki cirri-ciri yang unik dan khas. Ciri-ciri tersebut dapat menjadikan petunjuk adanya perbedaan antara produk seni dari daerah yang satu dengan daerah lainnya. Perbedaan ini disebabkan oleh lingkungan dimana seni kerajinan itu berkembang, juga disebabkan oleh kreativitas perajin itu sendiri. Lingkungan mempunyai pengaruh yang sangat besar pada perkembangan corak, bentuk dan jenis seni kerajinan. Hal ini terjadi karena adanya interaksi antara perajin, pengepul atau pengusaha kerajinan dan konsumen.

Seni kerajinan sarana upacara yang berkembang di desa Bresela kecamatan Payangan,desa Sebatu dan desa pejeng Tampaksiring banyak memproduksi jenis jenis dulang, bokoran, keben, tempat jrimpen, kapar dengan menggunakan bahan baku kayu dan feber glass. Bentuk dan jenis seni kerajinan ini sangat bervariasi dengan menawarkan berbagai kelebihan, baik model, fungsi, penampilan, dan kemasan. Keunggulan-keunggulan produk digarap dengan cermat oleh perajin untuk merangsang para konsumen tertarik pada produk yang dihasilkan. Banyak bentuk dan jenis produk seni kerajinan yang kini hadir dengan fungsi yang lebih praktis, sehingga masyarakat konsumen dapat memanfaatkan dengan cepat dan mudah. Demikian juga dalam membuat hiasann- 
ya selalu berkembang. Awalnya pembuatan bentuk dulang hanya menerapkan ornament tradisional Bali kemudian dikembangkan dengan menggunakan variasi kulit kerang sehingga penampilan bentuk dulang menjadi lebih menarik.

Bentuk Dulang atau wanci untuk sesajen gebogan yang dahulu dibuat hanya dasarnya, sekarang telah ditambah beberapa alas untuk tempat buah atau jajan. Pemasangannya sangat mudah, cepat, rapi, dan sehat karena segala sarana banten hanya ditumpuk dan tidak ada yang ditusuk, sehingga buah-buahan yang dipakai sebagai bahan sesajen tidak mudah busuk dan dapat dimakan.

Perkembangan bentuk-bentuk produk dulang atau wanci sangat cepat dari bentuk wanci yang menerapkan ornamen sederhana hingga menerapkan ornamen yang rumit dan unik. Dari bentuk bentuk dulang yang awalnya hanya berbentuk bundar kemudian berkembang dulang dengan bentuk segi delapan.

Dalam Pewarnaan produk sarana upacara lebih banyak menggunakan warna emas yang didapat dari warna prada, kemudian dikombinasikan dengan warna merah, sehingga produk kelihatan lebih mewah dan elegan. Perajin sangat kreatif dalam menciptakan bentuk-bentuk produk sarana upacara yang baru sehingga masyarakat konsumen terutama konsumen lokal selalu ingin membeli produk sarana upacara yang baru. Demikian juga dalam penerapan ornamennya dibuat semakin lebih variatif dipoles dengan warna gold prada, warna silver dikombinasikan dengan sigar warna sehingga semakin menambah nilai artistik dan nilai keindahan dari produk sarana upacara tersebut.

Berkembangnya jenis, teknik dan bentuk produk kerajinan sarana upacara di masing-masing desa di kabupaten Gianyar tidak terlepas dari kreativitas dan inovasi para perajin dalam menciptakan desain-desain baru yang disesuaikan dengan selera pasar. Seperti bentuk bokoran yang terbuat dari feber glass dan bokoran dari bahan baku kayu. Jenis bokoran yang terbuat dari bahan kayu ada yang di ukir manual dan ada yang dibuat sederhana tanpa diukir. Untuk menambah keindahan produk divariasikan dengan menerapkan ornamen Bali melalui teknik polesan warna warni cat minyak. Keindahan bentuk bokoran yang didukung oleh ornamen yang unik dan menarik menjadikan produk kerajinan selalu diburu konsumen, khususnya konsumen lokal.

Perajin sarana upacara sangat kreatif dalam menuangkan ide-ide barunya sehingga tercipta bentuk bentuk bokoran dengan berbagai ukuran. Perkembangan bentuk terlihat dari bentuk bokoran yang awalnya lebih banyak di buat dalam bentuk bulat kemudian berkembang bentuk-bentuk bokoran segi delapan. Usaha ini dilakukan oleh perajin agar konsumen tidak bosan dengan produk sarana upacara yang telah ada, sehingga timbul ide baru dari perajin untuk mengembangkan bentuk bokoran menjadi bentuk segi delapan. Dalam penerapan hiasannya juga semakin variatif, dengan mengkombinasikan motif-motif tradisional Bali seperti motif motif keketusan, motif pepatran dan motif kekarangan.

\section{Teknik Penciptaan Seni Kerajinan Sarana Upaca- ra}

Dalam proses penciptaan bentuk produk seni diperlukan adanya kreativitas dan kemampuan teknik. Franz Boas memandang keterkaitan bentuk dan teknik itu merupakan sesuatu yang selalu mengalami perkembangan sejalan dengan aktivitas manusia, karena alam dipandang tidak memberikan bentuk ideal, kecuali bila diberi sentuhan tangan-tangan terampil (Boas, 1955: 10) Selain itu mutu seni kerajinan ditentukan oleh nilai-nilai keindahan sesuai dengan fungsi gunanya dan nilai yang terkandung dalam kemampuan teknis. Sebagai karya seni, produk kerajinan harus menampilkan nilai estetis atau nilai keindahan rupa, sedangkan sebagai karya seni terapan, nilai estetis karya kerajinan tidak dapat dipisahkan dari nilai gunanya. Kemampuan teknis dalam penciptaan seni kerajinan adalah kemampuan untuk mengenal bahan, artinya mengenal watak bahan, mengolahnya dan mempergunakannya berdasarkan berbagai teknik. Pada seni kerajinan nilai teknis juga menentukan kualitas karya seninya, maka kemampuan atau ketrampilan teknis dalam seni kerajinan selain merupakan usaha mengeksplotasikan bahan juga untuk menciptakan bentuk yang mampu menjawab fungsi pakainya. Kemampuan teknik itu sendiri harus menjawab tuntutan keindahan dari seni kerajinan, oleh sebab itu perajin sarana upacara yang ada di Gianyar dalam menciptakan produk kerajinan selalu mempertimbangkan nilai fungsi, ergonomis, nilai teknik dan nilai keindahannya.

Apalagi sekarang ini telah ditemukannya teknik pembuatan sarana upacara yang lebih modern dengan teknik reproduksi yaitu teknik cetak dengan memanfaatkan bahan kimia. Perajin sarana upacara di desa Sebatu kecamatan Tegalalang, menggunakan teknik reproduksi dalam membuat produk kerajinannya. dengan adanya teknik reproduksi banyak perajin beralih memproduksi produk berupa dulang (wanci), sokasi (keben), dengan menggunakan teknik cetak.

Walaupun sebagian besar perajin sekarang ini memproduksi jenis produk yang sama dengan menggunakan teknik reproduksi, namun variasi ornamen- 

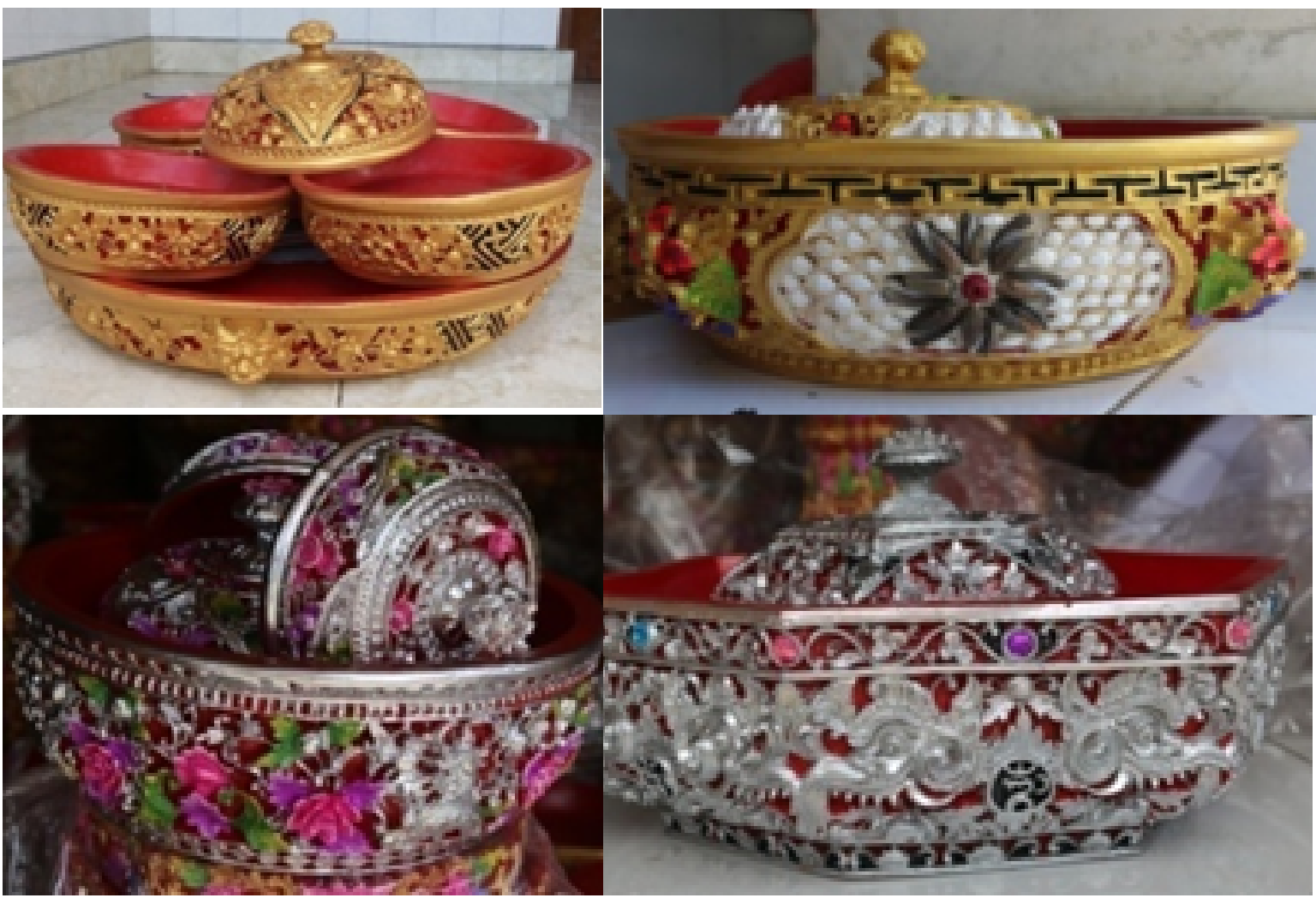

Gambar 2. Satu paket bokoran bulat untuk sesajen, kemudian berkembang Bokoran segi enam dengan warna perak.

Sumber: Perajin sarana upacara di desa Taro Tegalalang

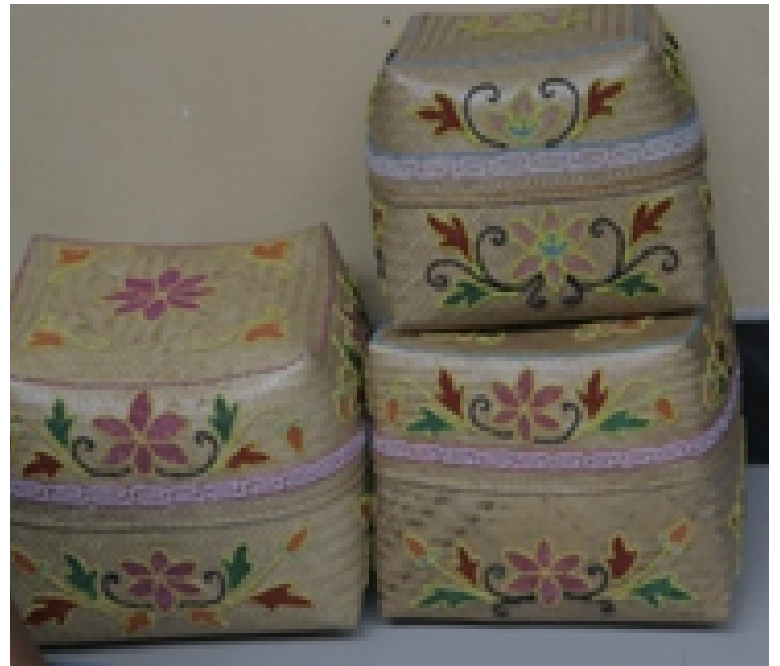

nya yang berbeda sehingga masyarakat konsumen dapat memilih produk yang bervariasi sesuai seleranya. Namun ada juga sebagian perajin yang masih bertahan membuat produk sarana upacara berupa dulang atau wanci dan bokoran yang berbahan baku kayu dengan teknik di tatah (ukir) secara manual.

Untuk memunculkan identitas Bali yang sangat kuat, semua produk dihiasi ornamen yang unik dan rumit.

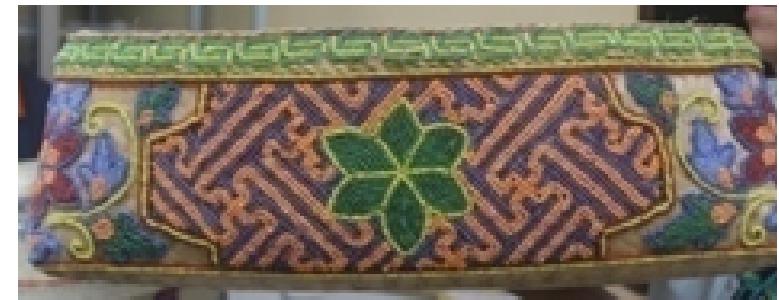

Gambar 3. Sarana upacara Tokasi dengan motif hias yang disulam.

Sumber : perajin desa Taro Tegalalang

Sebagian besar bidang dipenuhi dengan ukiran yang sangat menonjol dan di-finishing dengan warna emas yang membungkus seluruh ornamen, sehingga barang kelihatan sangat mewah dan elegan. Masyarakat akan merasa sangat senang dan bangga membawa sesajen ke Pura dengan sarana yang sangat mewah dan elegan. Mereka merasa telah mempersembahkan segala yang terbaik dan terindah pada Yang Kuasa.

Secara teknis, berkembangnya seni kerajinan sarana upacara disebabkan karena sangat didukung oleh teknologi modern yang ada. Perubahan teknis akan mempengaruhi pula kualitas seni kerajinan dan 


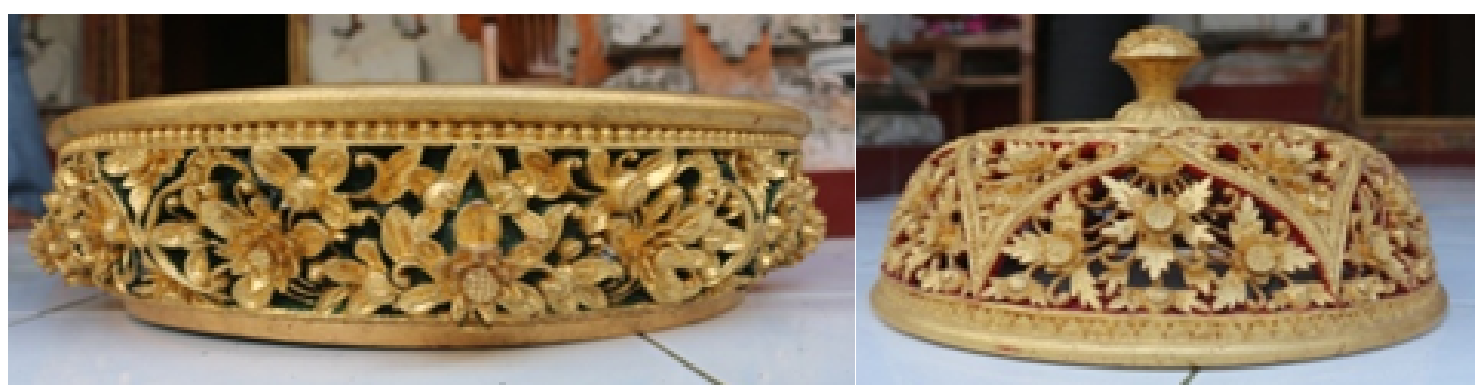

Gambar 4. bokoran yang berbahan baku kayu dengan teknik di tatah (ukir) secara manual.

ciri khas dari produk seni kerajinan yang diproduksi. Munculnya teknik reproduksi dalam penciptaan karya seni menyebabkan semua karya seni yang sifatnya massal dapat diciptakan dengan mudah dan cepat. Selama ini bahan yang digunakan dari kayu dan harus dikerjakan secara manual, sekarang telah dapat direproduksi dengan menggunakan bahan feber glass. Keunggulan dari penggunaan material ini, selain mudah dikerjakan, juga memiliki bobot yang sangat ringan dan sangat awet karena tidak bisa dimakan rayap. Ukiran ornamen juga dapat dimunculkan sangat menonjol dan rumit sesuai dengan contoh model yang digunakan.

Selain menggunakan feber glass, perajin di desa Sebatu kecamatan Tegalalang menciptakan produk sarana upacara juga memanfaatkan limbah gergaji dengan campuran lem kayu dicetak dengan teknik reproduksi. Jenis - jenis produk yang dibuat dengan teknik reproduksi dengan menggunakan limbah gergaji seperti wanci, bokoran, tempat gebogan, tempat genta, dan hiasan Salang. Apabila diperhatikan akan sangat sulit membedakan antara produk sarana upacara yang dicetak menggunakan feber dengan produk yang dicetak menggunakan limbah serbuk gergaji kayu. Perbedaannya hanya terdapat pada berat produk, yang mana produk berbahan limbah serbuk gergaji lebih berat dibandingkan dengan produk berbahan fiber.

Teknis finishing juga dapat dikerjakan dengan bantuan teknologi yang dapat disemprot langsung, tanpa dipoles. Pekerjaan ini dapat dilakukan terutama dalam membuat warna dasar, atau finishing produk dengan satu warna. Teknik polesan dapat dilakukan untuk membuat detail pada bagian-bagian tertentu, atau penggunaan warna yang beraneka ragam. Memerlukan keterampilan yang sangat ahli untuk membuat finishing dengan teknik polesan agar mendapatkan hasil yang lembut dan rapi. Teknik sunggingan dengan gradasi warna merupakan salah satu teknik finishing yang tepat diterapkan pada ukiran Apa itu teknik sungguinga?. Warna cerah merupakan identitas dari warna seni kerajinan sarana upacara yang menandakan bahwa barang tersebut sebagai suatu yang mewah dan gemerlap. Warna cerah memberi kesan yang gembira, riang, senang, yang merupakan perasaan seseorang yang sedang mempersembahkan sesuatu kepada Yang Kuasa. Dalam melakukan persembahan, tidak boleh perasaan yang sedih, duka, yang menandakan bahwa sujud bhakti yang tidak tulus dan murni. Secara visual warna cerah memperlihatkan sarana upacara tersebut mewah, elegan, indah sebagai tanda bahwa apa yang dipersembahakan merupakan sesuatu yang terindah dan terbaik.

Selain teknik reproduksi dengan ukiran yang menonjol, sarana upacara upacara juga banyak diciptakan dengan teknik yang lainnya, tergantung pada model, jenis dan fungsi barang tersebut. Teknik anyaman juga banyak digunakan dalam penciptaan seni kerajinan sarana upacara terutama pada jenis barang yang digunakan untuk tempat sesajen yang tertutup yang disebut Tokasi. Sarana ini biasanya digunakan untuk tempat sesajen bagi masyarakat yang ingin mengadakan sujud bhakti ke Pura-Pura yang jauh dari tempat tinggalnya. Masyarakat mulai banyak melakukan rekreasi sambil melakukan sembah bhakti pada Yang Kuasa yang disebut sebagai "Rekreasi Religius". Tokasi merupakan sarana upacara yang sangat tepat dimanfaatkan dalam melakukan rekreasi religius.

Dalam usaha mendekatkan diri dengan Yang Maha Kuasa, masyarakat lebih banyak melakukan rekreasi religius, maturan ke tempat-tempat suci yang tersebar di Bali. Sambil rekreasi pada suatu wilayah masyarakat langsung menghaturkan sembah bhakti pada Pura yang ada di tempat tersebut. Mereka sangat senang, selain mengenal suatu daerah, mereka dapat menghaturkan sembah dan dapat berkumpul bersama keluarga.Meningkatnya orientasi spiritual masyarakat dewasa ini merupakan implementasi dari wacana Ajeg Bali untuk menjaga budaya Bali yang dilandasi oleh Agama Hindu. Masyarakat merasa berkewajiban untuk ikut serta mengajegkan budaya Bali yang adiluhung agar tidak hilang begitu saja. Segala aktivitas adat dan agama dimunculkan dengan pelaksanaan yang menjunjung tinggi nilai-nilai budaya yang unik dan original. 


\section{Peranan Wacana Ajeg Bali Dalam Meningkatkan Dinamika Seni Kerajinan Sarana Upacara Di Gi- anyar Bali.}

Wacana Ajeg Bali berperan sangat besar dalam pengembangan seni kerajinan sarana upacara yang ada di Gianyar Bali. Tidak dapat dipungkiri dengan dibukanya Bali sebagai tujuan wisata utama Indonesia, tidak terlepas dari gempuran pengaruh luar yang sangat dasyiat. Banyak budaya luar yang datang dari berbagai arah mempengaruhi Bali dalam segala segi baik yang positif maupun negatif. Gempuran budaya Bali yang maha dasyiat memunculkan berbagai wacana, apakah kebalian Bali masih original, apakah kebalian orang Bali telah memudar, berubah, meninggalkan budaya tradisi yang adiluhung. Kebalian orang Bali terus menjadi sorotan, dan dianggap telah memudar karena adanya pengaruh luar yang sangat gencar. Sorotan ini bukan tanpa alasan, karena pola hidup dan tingkah laku orang Bali telah banyak yang berubah.

Suatu hal yang wajar, perkembangan jaman akan selalu berubah sesuai dengan dinamika kehidupan masyarakat pendukungnya. Dari jaman dahulu budaya Bali selalu mengalami perubahan karena mendapat pengaruh dari luar. Perubahan tersebut tidak membongkar dan mencabut budaya asli Bali, tetapi selalu saling pengaruhi dan terjadi akulturasi, sehingga lahir budaya baru yang diterima baik oleh masyarakat Bali. Budaya baru yang diterima dengan baik oleh masyarakat akan selalu berjalan dengan kehidupan masyarakat secara berkesinambungan, sehingga budaya baru tersebut menjadi budaya tradisi. Hal ini dapat dibuktikan dengan lahirnya budaya tradisi yang kental pengaruh dari luar seperti ragam hias Bali yang seperti patra Cina, Patra Wulanda, Patra Mesir, Patra Bangkok, dan yang lainnya.

Wacana Ajeg Bali adalah dalam usaha mempertahankan budaya Bali agar tidak hilang ditelan jaman. Dengan adanya wacana ini masyarakat merasa bertanggung jawab untuk melestarikan budaya Bali dengan berbagai kegiatan adat dan agama yang ditampilkan dengan identitas Bali yang sangat kental. Untuk menunjukan identitas lokal tentunya harus didukung oleh aktivitas dan artefak yang nilai original Bali, terutama yang berkaitan dengan sarana upacara adat dan agama, tidak saja tertuju pada sarana yang memiliki nilai religius, tetapi juga sarana yang memiliki fungsi propan. Masyarakat akan merasa malu apabila tidak mendukung wacana Ajeg Bali dengan ikut melestarikan budaya Bali.

Antusias masyarakat untuk bertanggung jawab dalam melestarikan budaya Bali yang diimplementasikan dengan melakukan aktivitas adat dan agama yang murni dan suci, menunjukan wacana Ajeg Bali berperan sangat besar dalam membentuk sikap masyarakat untuk mempertahankan budaya tradisi yang berjalan berdampingan dengan budaya modern. Dukungan sikap masyarakat yang diaktualisasikan dengan memanfaatkan berbagai sarana upacara yang sangat unik dan menarik, menandakan bahwa secara tidak langsung wacana Ajeg Bali berperan sangat besar dalam pengembangan sarana upacara yang ada di Gianyar. Dengan adanya wacana Ajeg Bali, masyarakat sangat antusias untuk memiliki berbagai bentuk dan fungsi sarana upacara yang dimanfaatkan untuk mendukung aktivitas adat dan agama yang dilaksanakan di rumahnya. Sarana upacara selain memiliki fungsi praktis, juga memiliki fungsi sosial di masyarakat. Status sosial masyarakat terkadang akan dinilai dari sarana upacara yang digunakan.

\section{SIMPULAN}

Wacana Ajeg Bali mempunyai peranan yang sangat besar dalam pengembangan seni kerajinan sarana upacara yang ada di Gianyar. Sebagai usaha untuk ikut serta dalam mengimplementasikan Ajeg Bali, masyarakat telah meningkatkan aktivitas adat dan agama dengan berbagai pelaksanaan upacara dan melakukan persembahyangan ke berbagai tempat suci, baik yang ada di Bali maupun luar Bali (Rekreasi religius). Untuk mendukung aktivitas tersebut, banyak sarana upacara yang dibutuhkan dengan berbagai bentuk dan fungsinya. Secara tidak langsung penciptaannya juga makin berkembang pesat.

Berbagai jenis dan bentuk sarana upacara yang telah tercipta dengan menawarkan berbagai keindahan dan kepraktisan dalam pemakaiannya. Bahan yang digunakan juga cukup bervariasi dengan teknik pengerjaan yang manual atau menggunakan teknologi sebagai alat bantunya. Dengan ditemukannya teknik reproduksi, penciptaan seni kerajinan sarana upacara berkembang sangat pesat dengan bentuk yang unik dan menarik. Teknik anyaman juga sangat mendominasi penciptaan seni kerajinan sarana upacara dengan menggunakan media bambu maupun rotan. Selain bentuk yang menarik, nilai estetika juga banyak dimunculkan dengan pembubuhan ornamen pada produk yang dilakukan dengan teknik ukiran maupun teknik sunggingan.

Sarana upacara tidak saja memenuhi fungsi praktis, tetapi juga sering dimanfaatkan sebagai fungsi sosial untuk menunjukan stratifikasi status sosial dalam masyarakat. Banyak masyarakat yang memilih sarana upacara yang mewah dan elegan, di samping ingin mempersembahkan yang terbaik pada Yang Kuasa, tetapi juga ingin menunjukan jati diri sebagai orang yang kaya pada masyarakat lain. Masyarakat akan 
sangat percaya diri apabila dalam mengusung sesajen menggunakan sarana upacara yang mewah dan gemerlap sebagai pertanda kehidupan mereka sudah mapan.

\section{DAFTAR RUJUKAN}

Agung, A.A. Gde Putra, (2005), Dialog Ajeg Bali Perspektif Pengamalan Agama Hindu, Paramita, Surabaya.

Ardana, I Gusti Gede,( 2007), Pemberdayaan Kearifan Lokal Masyarakat Bali Dalam Menghadapi Budaya Global, Pustaka Tarukan Agung, Denpasar.

Boas, Franz. (1955), Primitive Art, Dover Publictions, Inc, New York

Feldman, Edmund Burke, (1967), Art As Image and Ide, New Jersey: Prentice Hall, Inc, diterjemahkan oleh Gustami, 1991.

Maryanto, M. Dwi. (2002), Seni Kritik Seni, Lembaga Penelitian Institut Seni Indonesia, Yogyakarta.

Moleong, Lexy, J,( 2013), Metodologi Penelitian Kualitatif, PT Remaja Rosdakarya, Bandung.

Sahman, Humar. (1993), Mengenal Dunia Seni Rupa, IKIP Semarang Press, Semarang.

Soedarso SP, (2006), Trilogi Seni Penciptaaa Eksistensi dan Kegunaan Seni, BP. ISI.Yogyakarta. 